\title{
Left Atrial Dimension to Left Ventricle Ejection Fraction Ratio Can Predict Long- Term Major Adverse Events In Patients With Acute Coronary Syndrome
}

\section{Akut Koroner Sendrom Hastalarında Sol Atriyal Çapın Sol Ventrikül Ejeksiyon Fraksiyonuna Oranı Uzun Dönem Major İstenmeyen Olayları Öngörebilir}

\author{
Ömer Faruk ÇIRAKOĞLU ${ }^{1}(\mathbb{D})$, Ahmet Seyda YILMAZ ${ }^{2}$ (D) , Göksel ÇINIER ${ }^{3}(\mathbb{D})$, Mustafa ÇETiN ${ }^{2}(\mathbb{D})$ \\ ${ }^{1}$ Ahi Evren Training and Research Hospital, University of Health Science, Department of Cardiology, Trabzon, Turkey \\ 2 Recep Tayyip Erdogan University, Faculty of Medicine, Department of Cardiology, Rize, Turkey \\ ${ }^{3}$ Siyami Ersek Training and Research Hospital, University of Health Science, Department of Cardiology, İstanbul, Turkey
}

\section{Abstract}

Background: It is critical to specify the high-risk group in acute coronary syndrome following percutaneous coronary intervention. Left atrial diameter and Left ventricle ejection fraction are functional echocardiographic parameters for risk classification thanks to easy obtainable, cheap, and non-invasive nature. However, major adverse cardiovascular events may be predicted less than actual where ejection fraction or left atrial diameter are in the normal range. We aimed to assess the left atrial diameter to ejection fraction ratio for major adverse cardiovascular events prediction in acute coronary syndrome.

Materials and Methods: Individuals with acute coronary syndrome were included in the study. Atrial diameter and ejection fraction parameters were obtained at admission. The left atrial diameter to left ventricular ejection fraction ratio was calculated through atrial diameter dividing by ejection fraction, and the relationship between new-onset heart failure and all-cause mortality with this ratio was investigated for two years period.

Results: The mean age of total 262 patients were $62.1 \pm 11.5$ years. Thirty-nine $(18.9 \%)$ of patients were female and major adverse cardiovascular events occurred in $73(28 \%)$ of the patients. In the backward multivariable Cox regression analysis, age [Hazard ratio $(H R)=1.039,95 \% \mathrm{Cl}: 1.017-1.060, p<0.001]$, Killip class [HR=2.099, 95\% Cl:1.011-4.365, $\mathrm{p}=0.045$ ], serum creatinine level [HR=2.202, 95\%Cl:1.247-3.811, $\mathrm{p}=0.003$ ], and left atrial diameter to left ventricular ejection fraction ratio $[H R=1.029,95 \% \mathrm{Cl}: 1.019-1.038, p<0.001]$ were revealed to be independent predictors of major adverse events.

Conclusion: Left atrial diameter to left ventricular ejection fraction ratio were predictors of two years new-onset heart failure and mortality in acute coronary syndrome. This novel practical index may provide better prediction for adverse events in all patient groups.

Key Words: Acute coronary syndrome (ACS), Left atrial diameter (LAd), Left ventricle ejection fraction (LVEF), Left atrial diameter (LAd) to Left ventricle ejection fraction (LVEF) ratio (LAd/LVEF)

Öz.

Amaç: Akut koroner sendromlu hastalarda perkütan koroner girişim sonrası yüksek riskli grupların belirlenmesi oldukça önemlidir. Sol ventrikül ejeksiyon fraksiyonu ve sol atrium çapı, kolay elde edilebilebilir, ucuz ve invaziv olmaması nedeniyle risk sınıflandırması için fonksiyonel ekokardiyografik parametrelerdir. Bununla birlikte, majör istenmeyen kardiyovasküler olaylar, ejeksiyon fraksiyonu veya atrium çapının normal aralıkta olduğu durumlarda gerçek olandan daha az tahmin edilebilir. Bu nedenle akut koroner sendrom hastalarında majör istenmeyen olay öngörüsü için sol atrium çapının sol ventrikül ejeksiyon fraksiyonuna oranının değerlendirilmesini amaçladık.

Materyal ve Metod: Çalışmaya akut koroner sendrom tanısı almış hastalar dahil edildi. Tüm hastalardan sol ventrikül ejeksiyon fraksiyonu ve sol atrium çapları parametreleri başvuru sırasında elde edildi. Sol atrial çapın sol ventrikül ejeksiyon fraksiyonuna oranı, sol atriyal çapın ejeksiyon fraksiyonuna bölünmesi ile hesaplandı ve 2 yıllık takiplerde tüm nedenlere bağlı ölüm ve yeni başlayan kalp yetmezliği ile olan ilişkisi incelendi.

Bulgular: Toplam 262 hastanın ortalama yaşı $62.1 \pm 11.5$ yıldı. Hastaların 39 'u (\%18.9) kadındı ve major istenmeyen kardiyovasküler olay 73 (\%28) hastada meydana geldi. Geriye dönük çok değişkenli Cox regresyon analizinde, yaş [Hazard ratio (HR)=1.039, 95\%Cl:1.017-1.060, $p<0.001$ ], Killip sınıfı [HR=2.099, 95\%Cl:1.011-4.365, $p=0.045]$, serum kreatinin düzeyi [HR=2.202,95\%Cl:1.247-3.811, $\mathrm{p}=0.003$ ], ve sol atrial çapın sol ventrikül ejeksiyon fraksiyonuna oranı [HR=1.029, 95\%Cl:1.019-1.038, $\mathrm{p}<0.001]$ major istenmeyen olayların bağımsız prediktörleri olarak bulundu.

Sonuç: Sol atrial çapın sol ventrikül ejeksiyon fraksiyonuna oranı, akut koroner sendrom hastalarında 2 yıllık yeni tanı kalp yetmezliği ve ölümün bağımsız prediktörleriydi. Bu yeni pratik index istenmeyen olayların öngörülmesi için tüm hasta gruplarında daha fazla öngörü sağlayabilir.

Anahtar kelimeler: Akut koroner sendrom (AKS), Sol atriyal çap (SAç), Sol ventrikül ejeksiyon fraksiyonu (SVef), Sol atriyal çap (SAç)-Sol ventrikül ejeksiyon fraksiyonu (SVef) oranı (SAç/SVef)
Sorumlu Yazar / Corresponding Author

Ahmet Seyda YILMAZ

Recep Tayyip Erdogan University,

Faculty of Medicine,

Department of Cardiology

53020, Rize, Turkey

E-mail: ahmetseydayilmaz@gmail.com

Geliş tarihi / Received:

05.06.2021

Kabul tarihi / Accepted:

20.08.2021

DOI: 10.35440/hutfd.948089

This manuscript was presented orally with SB-148 number at the 36th Turkish Cardiology Congress on 5 December 2020. 


\section{Introduction}

Acute coronary syndrome (ACS) is leading cause of adverse cardiovascular events globally, despite improvement in modern medical and interventional treatment options, in recent decades. Nowadays, several clinical indicators have been recognized predicting prognosis in patients with ACS (1). However, easily applicable and costeffective indices continue to be research subject for better outcome prediction.

Left atrium (LA), rather being an inactive cavity, has a pivotal role in diastole by functioning as a channel in the early phase of and as a promoter pump in the late phase of ventricular filling. Furthermore, the impaired atrial function was shown to induce atrial fibrillation (AF), heart failure, and to increase mortality. Potential determinants of atrial myopathy were shown to be left atrial enlargement, premature atrial contractions and atrial fibrosis $(2,3)$. Left atrial diameter (LAd) is easily applicable, costeffective, and the simplest marker showing atrial remodeling and functions among left atrial enlargement indices. Besides, increased LAd was found to be precipitated arterial hypertension, $A F$, and stroke in normal population and ACS patients $(4,5)$.

Left ventricular ejection fraction (LVEF) is examined to evaluate current clinical status in patients with ACS, routinely (6). However, in case of the preserved left ventricular ejection fraction or atrial size, the outcome can be undervalued than actual it is. Therefore, we postulated that the combined usage of LAd and LVEF might augment prognostication. For that purpose, it was aimed to examine the role of LAd to LVEF ratio (LAd/LVEF) as a novel echocardiographic parameter in major cardiovascular adverse events (MACE) prediction in ACS patients in long term follow-up.

\section{Materials and Methods}

\section{Study population}

It was a retrospective, observational cohort study. A total of 262 consecutive patients with cardiac symptoms were assessed furtherly. Patients with $\geq 1 \mathrm{~mm}$ ST-elevation in consecutive leads related to one of the major coronary arteries' territories on electrocardiography (ECG) were accepted ST elevated Myocardial Infarction (STEMI) and delivered to angiography laboratory, immediately. In addition, those with ischemic ST-segment depression, or T wave inversion were taken blood sample for cardiac biomarkers. Elevation in Troponin I/T or creatine kinase (CK/MB) levels were considered to be non-ST-segment elevation myocardial infarction (NSTEMI). Patients with abovementioned symptoms and ECG findings without cardiac biomarker elevations were considered to be unstable angina pectoris (USAP) and also included in the analysis $(7,8)$. Any type of malignancy, pulmonary embolism, history of coronary artery disease, congenital heart disease, moderate to severe renal and liver failure, collagenous vascular disease, myocarditis, acute inflammatory disease, history of cerebrovascular disease, moderate to severe valvular cardiac disease, and all types of cardiomyopathies including restrictive and hypertrophic were determined as exclusion criteria. Permission was obtained from the Local Ethics Committee of Recep Tayyip Erdogan University Ethic Committee numbered by 40465587 050.01.04 on 24.06.2020.

\section{Demographical and laboratory data}

Detailed medical history and demographic features, and routine blood analysis were obtained from each participant at admission and were stored in our institution's database. Killip class for risk classification were evaluated. Hypertension and Diabetes Mellitus diagnosis were generated following the current guidelines $(9,10)$. Family history presence of CAD was expressed as the development of atherosclerotic cardiovascular disease (CVD) or death from CVD in a first-degree relative (ie, parent or sibling) prior to age 55 for males or 65 for females (11). Body mass index (BMI) was obtained with the following formula: weight/height $(\mathrm{cm})^{2}$.

\section{Transthoracic echocardiographic evaluation}

Two-dimensional M-mode transthoracic echocardiography was completed for all patients via the EPIQ 7C ultrasound system (Philips, Best, The Netherlands) at admission. LA and LV dimensions and wall thicknesses were gained at parasternal long-axis images. LVEF was obtained according to the modified Simpson's method. The LAd was considered as the length between the posterior aortic valve and the rear left atrial wall in the end-systolic, parasternal long-axis view. The LAd/LVEF was calculated through LAd dividing by LVEF.

\section{Selective coronary angiography}

Primary $\mathrm{PCl}$ was performed immediately after admission to all patients presented with STEMI. Patients with unstable angina pectoris (USAP) and NSTEMI underwent PCI by the Judkins method urgently from the peripheral arteries. Left anterior descending and left circumflex coronary arteries were visualized at least from four different angles; and the right coronary artery was at least two angles. Balloon angioplasty was performed before coronary stenting or stent was placed directly where eligible. Basal TIMI (thrombolysis in myocardial infarction) flow grade was assessed at first angiogram (12). All patient's evaluation was performed by two independent interventional cardiologists at the beginning of the investigation. All obtained data, coronary angiography views, and results were recorded in the database of ours institute.

Patients were given the loading dose of clopidogrel, acetylsalicylic acid, and intravenous heparin prior to procedure. Patients were taken into the intensive coronary unit (ICU) till stabilization is ensured.

\section{Clinical follow-up}

New onset decompensated heart failure (HF) and allcause mortality during two years of follow-up was determined as MACE. All patients were recruited to routine outpatient clinics on the 1st, 3rd, 6th, 12th months, and 
second year after discharge. Echocardiographic findings, physical examination, and laboratory data of each patient were obtained from hospital admission records, national databases, and direct phone calls or face-to-face interviews with patients or relatives of relevant patients. Typical heart failure symptoms including shortness of breath, swelling of ankles, palpitation, weakness, and jugular venous fullness, pulmonary congestion, and peripheral edema were assessed at these examinations. Patients with the abovementioned symptoms and physical examination findings, and with LVEF under the $40 \%$ were accepted as congestive heart failure (CHF).

\section{Statistical analysis}

A 23.0 version SPSS software package (Inc., Chicago, IL) was employed to analyze the obtained data. Statistical significance was considered to be the $p$-value of less than 0.05 . The normality assumption of data was assessed by the Kolmogorov-Smirnov/Shapiro-Wilk's test. Levene's test was used to check the homogeneity of variances. While the mean \pm standard deviation scheme was used to represent the continuous variables, the percentages was used to present the categorical variables. The Chi-square or Fisher's exact test was employed for the purpose of comparing the categorical groups. While the 2-tailed Student t-test was conducted for parameters that normally distributed, Mann-Whitney $U$ test was implemented for the abnormally distributed continuous variables. The univariate regression analysis was carried out to assess the effects of the various variables on MACE. The variables with unadjusted $p<0.05$ were considered to be confounding factors and included in the backward multivariable Cox regression analysis to reveal the independent predictors of MACE. Areas under the receiver operating characteristic (ROC) curve analysis was applied to estimate the predictive values of LAd, LVEF, and LAd/LVEF. KaplanMeier curve was drawn to show the LAd, LVEF, and LAd/LVEF percentiles in predicting MACE.

\section{Results}

The study consisted of total 262 patients and 39 (14.8\%) of them were female. MACE was defined as new-onset HF and all-cause mortality, which was occurred in 73 (28\%) patients during two years of follow-up. Patients were separated into two groups as regard to the presence of the MACE. Patients in MACE $(+)$ group were older $(67.2 \pm 12$ vs $60.1 \pm 10.6, p<0.001)$ and more likely to be male $(20.2 \%$ vs $7.6 \%, p=0.021)$. DM and HT rates were higher (49.3\% vs $37.6 \%, p=0.042 ; 69.9 \%$ vs $54.5 \%, p=0.016$, respectively) in patients with MACE $(+)$. In addition, admission serum creatinine level $(1.13 \pm 0.43$ vs $0.95 \pm 0.22 \mathrm{mg} / \mathrm{dL} ; \mathrm{P}<0.001)$ and CRP (0.65 [0.35-1.25] vs 0.98 [0.52-2.5], $\mathrm{P}=0.018$ ) were higher in MACE $(+)$ group (Table 1$)$.

Patients with STEMI more likely to have MACE as compared to patients with NSTEMI or USAP (40\% vs $18.7 \%$, $\mathrm{P}<0.001)$. LAd and LAd/LVEF were higher $(39.7 \pm 5.7$ vs
$37.2 \pm 4.3, p<0,001 ; 86.7 \pm 28.3$ vs $69.4 \pm 16.9, p<0,001$, respectively) and LVEF was lower $(49.1 \pm 11.3$ vs $55.3 \pm 8.1$, $\mathrm{P}<0,001)$ in univariate analyze in patients with MACE (Table 1).

In the backward multivarible Cox regression analysis, age [Hazard ratio $(\mathrm{HR})=1.039,95 \%$ Confidence interval $(\mathrm{Cl})$ : 1.017-1.060, $p<0.001]$, serum creatinine $[H R=2.202$, 95\% Cl: 1.247-3.811, $\mathrm{p}=0.003$ ], Killip class $[\mathrm{HR}=2.099$, 95\%Cl: 1.011-4.365, $p=0.045]$, and LAd/LVEF [HR=1.029, $95 \% \mathrm{Cl}: 1.019-1.038, \mathrm{p}<0.001]$ were independent predictors of MACE after 2 years follow up (Table 2 ).

The area under curve (AUC) for LAd/LVEF was 0.703 (95\% $\mathrm{Cl}: 0.690-0.806, \mathrm{p}<0.001)$ in predicting MACE in receiver operating characteristic (ROC) analysis. In addition, the AUC for Lad and LVEF were found as 0.634 and 0.663 respectively in ROC analysis (Figure 1). The sensitivity and specificity of LAd/LVEF $>81.5$ were $76.2 \%$ and $84.5 \%$ respectively in predicting MACE.

Cumulative survival analysis of LAd, LVEF, and LAd/LVEF were evaluated by Kaplan-Meier curves and presented in a single graphical image including each parameter. It was revealed that higher LAd/LVEF augmented the risk of allcause death more than LAd and LVEF alone (Figure 2). Kaplan-Meier curve demonstrated that higher LAd/LVEF increased the risk of MACE beginning from the early follow up (Figure 3).

\section{Discussion}

In the current study, it was found that age, Killip class, serum creatinine, and LAd/LVEF were independent predictors of MACE in patients with ACS who underwent $\mathrm{PCl}$ after 2 years follow up. To the best of our knowledge, LAd/LVEF has not been evaluated previously in predicting MACE.

The attention in the LA increased in recent years thanks to its complex property. LA takes a crucial role in the cardiac circulation as an effective channel for pulmonary venous blood in early ventricular diastole and as pump increasing ventricular filling in late ventricular diastole. Therefore, left atrial function indicators are indirect indices of LV chamber compliance as well as LV volume $(2,3)$. However, diminished diastolic function was shown to be associated with MACE in patients with ACS, it was reported not to be apparent clinically in most of the cases. For this reason, left atrial measurements such as left atrial diameter, volume, and functions were used to be an indicator of diastolic dysfunction in several studies (13-16). M-mode echocardiography is conducted to all patients prior to coronary intervention in clinical practice because it is simple, cheap, non-invasive, and easily applicable technique. Especially, in patients who can't stand to lie in a supine position until underwent $\mathrm{PCl}$, not volume indices but $\mathrm{M}$-mode diameter measurements can be obtained rapidly at emergent conditions. LAd obtained by M-mode echocardiography is the simplest measurement among left atrial function and structure parameters. 
Table 1. Demographic, Angiographic, Laboratory and Echocardiographic Data

\begin{tabular}{|c|c|c|c|c|}
\hline Variable & $\begin{array}{l}\text { MACE (-) } \\
(n=189)\end{array}$ & $\begin{array}{l}\text { MACE }(+) \\
(n=73)\end{array}$ & $\begin{array}{l}\text { All Patient } \\
(\mathrm{n}=262)\end{array}$ & p \\
\hline Gender (Male) & $160(84.7)$ & $53(72.9)$ & $213(81.7)$ & 0.021 \\
\hline Age (year) & $60.1 \pm 10.6$ & $67.2 \pm 12$ & $62.1 \pm 11.5$ & $<0.001$ \\
\hline Hypertension n (\%) & $103(54.5)$ & $51(69.9)$ & $154(58.8)$ & 0.016 \\
\hline Current smoker n (\%) & $81(42.9)$ & $22(30.1)$ & $103(39.3)$ & 0.059 \\
\hline Hyperlipidemia n (\%) & 70(37) & $26(35.6)$ & $96(36.6)$ & 0.474 \\
\hline Diabetes mellitus $\mathrm{n}(\%)$ & $71(37.6)$ & $36(49.3)$ & $107(40.8)$ & 0.056 \\
\hline $\mathrm{BMI}\left(\mathrm{kg} / \mathrm{m}^{2}\right) *$ & $29.4(25.9-32.8)$ & $28.7(25.2-34.6)$ & $29.4(26.1-33.2)$ & 0.895 \\
\hline Previous CAD n (\%) & $32(17.2)$ & $16(22.5)$ & $48(18.7)$ & 0.210 \\
\hline Systolic BP * & $130(120-140)$ & $130(110-145)$ & $130(120-140)$ & 0.919 \\
\hline Diastolic BP * & $80(70-84.7)$ & $80(70-89)$ & $80(70-85)$ & 0.506 \\
\hline Heart rate (bpm) & $77.6 \pm 14.8$ & $81.6 \pm 15.4$ & $78.7 \pm 15.1$ & 0.041 \\
\hline $\begin{array}{l}\text { Diagnosis } \\
\text { USAP/NSTEMI } \\
\text { STEMI }\end{array}$ & $\begin{array}{l}126(66.7) \\
66(33.3)\end{array}$ & $\begin{array}{l}29(39.7) \\
44(60.3)\end{array}$ & $\begin{array}{l}155(59.7) \\
110(40.3)\end{array}$ & $<0.001$ \\
\hline $\begin{array}{l}\text { Killip class } \\
1 \\
>1\end{array}$ & $\begin{array}{l}187(98.9) \\
2(1.1)\end{array}$ & $\begin{array}{l}63(87.5) \\
9(12.5)\end{array}$ & $\begin{array}{r}250(95.8) \\
11(4.2)\end{array}$ & $<0.001$ \\
\hline $\begin{array}{l}\text { Myocardial Blush } \\
0-1 \\
2 \\
3 \\
\end{array}$ & $\begin{array}{l}41(22 \%) \\
53(28.3) \\
93(49.6)\end{array}$ & $\begin{array}{l}37(50 \%) \\
20(28.2) \\
16(22)\end{array}$ & $\begin{array}{l}78(29.7) \\
73(27.8) \\
109(41.6)\end{array}$ & $<0.001$ \\
\hline $\begin{array}{l}\text { Responsible coronary artery } \\
\text { LAD } \\
\text { RCA } \\
\text { CX }\end{array}$ & $\begin{array}{l}84(44.5) \\
61(32.4) \\
43(23.1)\end{array}$ & $\begin{array}{l}33(44.9) \\
24(33.3) \\
16(21.7)\end{array}$ & $\begin{array}{l}117(44.6) \\
85(32.6) \\
59(22.8)\end{array}$ & 0.183 \\
\hline Stent length $(\mathrm{mm}) *$ & $22(18-30)$ & $25.5(18-32.5)$ & $22(18-30)$ & 0.325 \\
\hline Stent diameter $(\mathrm{mm}) *$ & $3(2.75-3)$ & $3(2.75-3)$ & $3(2.75-3)$ & 0.686 \\
\hline Peak CKMB (ng/mL) & $66.6 \pm 89.9$ & $116.1 \pm 113$ & $80.5 \pm 99$ & $<0.001$ \\
\hline Peak Troponin (ng/mL) & $20.5 \pm 20.6$ & $31.3 \pm 20.6$ & $23.5 \pm 21.1$ & $<0.001$ \\
\hline Fasting glucose (mg/dl) & $143 \pm 66$ & $167 \pm 75$ & $150 \pm 69$ & 0.016 \\
\hline $\mathrm{Cr}(\mathrm{mg} / \mathrm{dl})$ & $0.65 \pm 0.22$ & $1.13 \pm 0.43$ & $1.05 \pm 0.31$ & $<0.001$ \\
\hline $\mathrm{CRP}(\mathrm{mg} / \mathrm{L}) *$ & $0.65(0.35-1.25)$ & $0.98(0.52-2.5)$ & $0.69(0.37-1.3)$ & 0.018 \\
\hline Hemoglobin (gr/dL) & $14.3 \pm 1.8$ & $13.8 \pm 1.9$ & $14.2 \pm 1.8$ & 0.088 \\
\hline $\operatorname{WBC}\left(10^{3} / \mu \mathrm{L}\right) *$ & $9.7(7.9-12)$ & $10.1(8-13.4)$ & $9.8(7.9-12.1)$ & 0.393 \\
\hline ACEI / ARB & $155(83)$ & $58(79.5)$ & $213(81.2)$ & 0.081 \\
\hline ASA & $187(99.2)$ & $67(93.2)$ & $254(96.5)$ & 0.520 \\
\hline Beta blocker & $131(69.5)$ & $53(73)$ & $184(70.2)$ & 0.139 \\
\hline CCB & $43(23)$ & $14(20.1)$ & $57(21.7)$ & 0.165 \\
\hline Statin & $167(88.3)$ & $58(79.5)$ & $265(85.8)$ & 0.119 \\
\hline OAD/Insulin & $67(35.3)$ & $34(46.4)$ & $101(38.5)$ & 0.067 \\
\hline LVef & $55.3 \pm 8.1$ & $49.1 \pm 11.3$ & $53.5 \pm 9.4$ & $<0.001$ \\
\hline LA diameter & $37.2 \pm 4.3$ & $39.7 \pm 5.7$ & $37.9 \pm 4.8$ & $<0.001$ \\
\hline LAd/LVefr & $69.4 \pm 16.9$ & $86.7 \pm 28.3$ & $74.2 \pm 22.1$ & $<0.001$ \\
\hline
\end{tabular}

BMI: Body mass index, CAD: Coronary artery disease, BP: Blood pressure, USAP: Unstable angina pectoris, NSTEMI: Non-ST Elevated myocardial infarction, STEMI: ST-Elevated myocardial infarction, LAD: Left Anterior Descending Artery, RCA: Right Coronary Artery, CX: Circumflex Artery, CKMB: Creatine Kinase, Cr: Creatinine, CRP: C reactive protein, WBC: White blood cell count, ACEI/ARB: Angiotensin converting enzyme inhbitor/angiotensin receptor blocker, ASA: Acetylsalicylic acid, CCB: Calcium channel blocker, OAD: Oral anti-diabetic, LVef: Left Ventricle Ejection Fraction, LA: Left atrium, LAd/LVefr: Left atrium to Left ventricle ejection fraction rate

*Median value (25\%-75\% value)

Besides, LAd was found to be strongly associated with LV hypertrophy and eccentric geometry and LA volume measurements (17-19). Besides, the left atrial enlargement promotes blood stasis and increases the risk for AF and stroke consequently. AF is also a well-established risk factor for heart failure, stroke, and mortality, particularly in patients with ACS (4). In addition, LAd was found to be related to AF duration and arrhythmic burden and therefore it was suggested to being a virtuous marker for risk stratification in patients with $\operatorname{AF}(16,17)$. Besides, Mo et al showed LAd when added to CHADS-VASC score improved the mortality and stroke prediction in patients with sick sinus syndrome (21). With that in mind, we think that LAd elevation might be responsible for increased MACE by also inducing AF. In addition, LA modulates the hemodynamic balance by secreting atrial natriuretic peptide (ANP) respond to stretch of atrial wall. The ANP modulates the counterbalance between renin-angiotensin-aldosterone and parasympathetic system by providing natriuresis and vasodilatation. Thus, left atrium was regarded as one of the components of neuroendocrine system. 
Table 2. Cox Regression Analysis for independent predictors of MACE

\begin{tabular}{|c|c|c|c|c|c|c|}
\hline \multirow[b]{2}{*}{ Variable } & \multicolumn{3}{|c|}{ Univariate } & \multicolumn{3}{|c|}{ Multivariate } \\
\hline & HR & $95 \% \mathrm{Cl}$ & $p$ & HR & $95 \% \mathrm{Cl}$ & $p$ \\
\hline Gender (Male) & 0.525 & $0.313-0.879$ & 0.014 & & & \\
\hline Age (year) & 1.050 & $1.029-1.071$ & $<0.001$ & 1.039 & $1.017-1.060$ & $<0.001$ \\
\hline Diagnosis & 2.590 & $1.620-4.142$ & $<0.001$ & & & \\
\hline Hypertension & 1.640 & $0.994-2.707$ & 0.053 & & & \\
\hline Current smoker & 0.877 & $0.680-1.130$ & 0.309 & & & \\
\hline Heart rate & 1.016 & $1.001-1.031$ & 0.041 & & & \\
\hline Killip class & 5.170 & $2.552-10.47$ & $<0.001$ & 2.099 & $1.011-4.365$ & 0.045 \\
\hline Peak Troponin & 1.020 & $1.009-1.031$ & $<0.001$ & & & \\
\hline Fasting glucose & 1.004 & $1.001-1.007$ & 0.009 & & & \\
\hline Diabetes mellitus & 1.542 & $0.973-2.411$ & 0.063 & & & \\
\hline Serum creatinine & 3.378 & $2.092-5.454$ & $<0.001$ & 2.202 & $1.274-3.811$ & 0.003 \\
\hline CRP & 1.075 & $1.012-1.141$ & 0.018 & & & \\
\hline Hemoglobin & 0.897 & $0.801-1.005$ & 0.061 & & & \\
\hline WBC & 1.055 & $0.978-1.138$ & 0.166 & & & \\
\hline LAd/LVefr & 1.030 & $1.022-1.038$ & $<0.001$ & 1.029 & $1.019-1.038$ & $<0.001$ \\
\hline
\end{tabular}

CK-MB: Creatine Kinase, CRP: C reactive protein, LA: Left atrium, LAd/LVefr: Left atrium to Left ventricle ejection fraction rate, LVEF: Left Ventricle Ejection Fraction, WBC: White blood count.

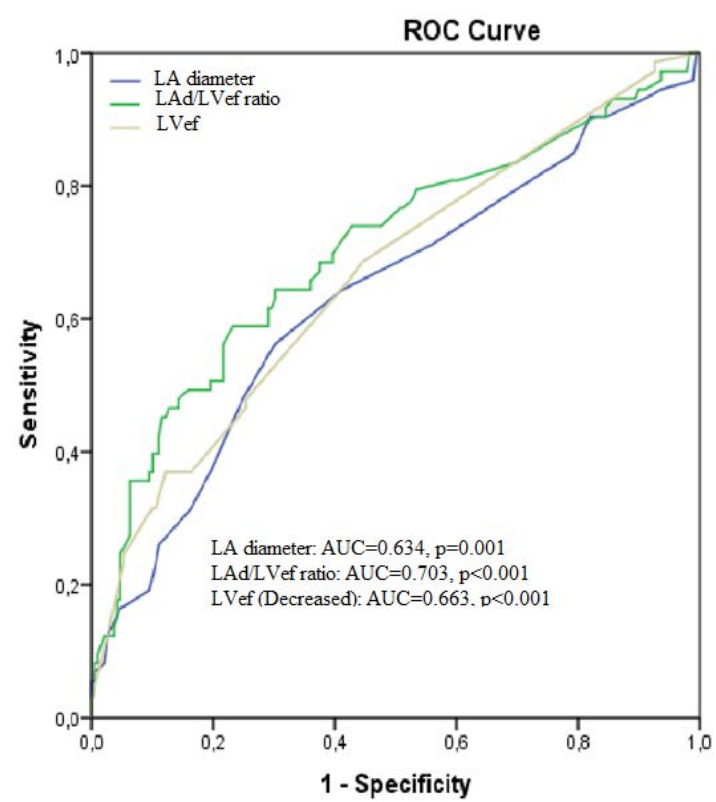

Diagonal segments are produced by ties.

Figure 1: Receiver operating characteristic (ROC) curves for LAd, LAd/LVEF ratio and LVEF for predicting MACE. (LA: Left atrial diameter, LAd/LVEF: Left atrium to Left ventricle ejection fraction rate, LVEF: Left ventricle)

Pressure or volume overload in left atrium promote left atrial enlargement $(2,22)$. Therefore, we thought that LAd might be related to MACE by this way.

The LVEF is examined at admission and during follow-up and is also well established to be related to outcomes in patients with ACS $(6,23)$. Boch et al. found that LVEF has more predictive value than other echocardiographic parameters predicting MACE in patients with ACS. In addition, in patients whose LVEF was under $48 \%$, the mortality rate was 3.3-fold higher (24). While in the present study, MACE was shown to be related to decreased LVEF, it was eliminated the predictive value of LVEF and LAd by multivariable regression analysis. This could be owing to the limited number of patients or to LVEF and LAd were relatively close to the normal range. On the other hand, this could mean that left atrial enlargement or deteriorated left ventricular systolic function might be scarce to predict future adverse events alone. In addition, in case of elevated LAd and normal LVEF or normal LAd and decreased LVEF, we may need a further tool for outcome prediction because of effects of LAd and LVEF balance each other. Meanwhile, in the early stage of ACS, tachycardia, transient ischemic dysfunction, stunning, or hibernation may occur and the LVEF may show variability subsequently. Therefore, the utilization of quantitative and combined indices may provide a more objective prediction of outcomes. It was shown that adding LVEF to other scoring tools elicit more accurate results in outcome prediction (24). With that in mind, we think the combined usage of LAd and LVEF might facilitate MACE prediction as compared to their single usage.

Heart failure with preserved ejection fraction (HFpEF) accounts for almost half of all types of heart failure. Morbidity and mortality rates, and quality of life in patients with HFpEF can be worse than with reduced ejection fraction (25). It does not exist a single objective marker to define HFpEF then its diagnosis is challenging. Therefore, these patients are evaluated by measuring diastolic parameters. HFpEF is suspected in patients with symptoms and findings of heart failure accompanying to structural heart diseases such as left atrial enlargement or left ventricular hypertrophy (26). However, it was multisystemic disease and might present with non-cardiac complaints. Therefore, patients without specific signs and symptoms of HFpEF can easily be disregarded (27). 


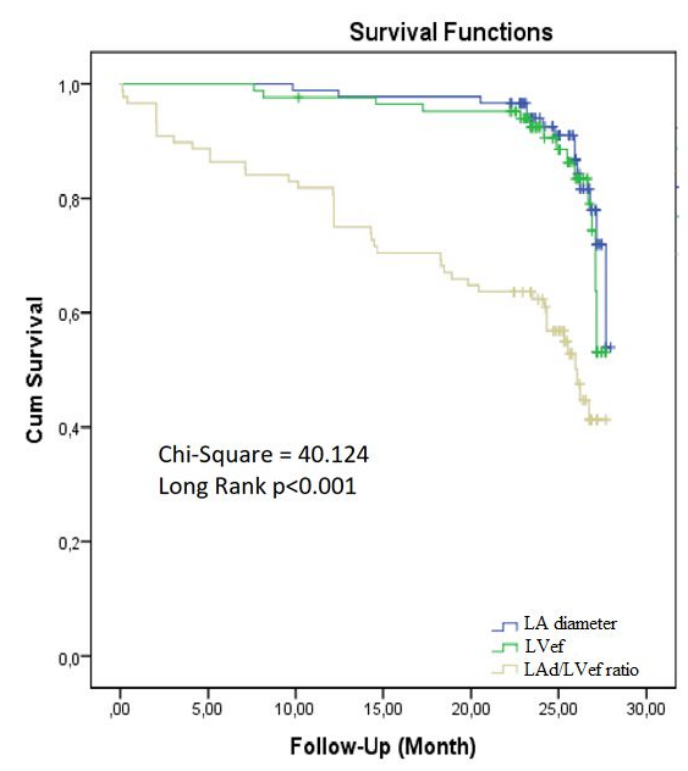

Figure 2. Kaplan-Meier curves for LAd, LAd/LVEF ratio and LVEF for MACE risk.

( LA: Left atrial diameter, LAd/LVEF: Left atrium to Left ventricle ejection fraction rate, LVEF: Left ventricle, MACE: Major adverse cardiovascular event)

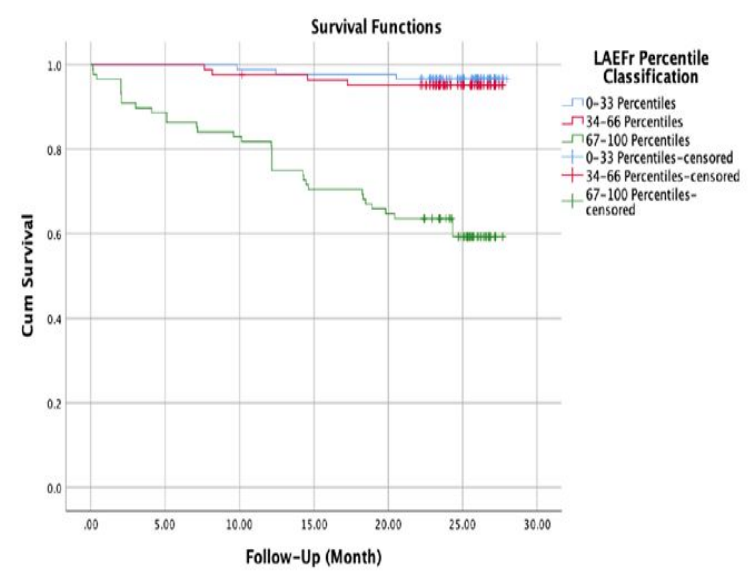

Figure 3. Kaplan-Meier curves demonstrated that higher LAd/LVEF ratio increased the risk of all-cause death beginning from the early follow-up.

(LAd/LVEF: Left atrium to Left ventricle ejection fraction rate)

On the other hand, ACS was shown to be one of the risk factors of HFpEF (28). Antonelli et al. showed that those who were developed HFpEF had a 3-fold higher mortality risk than those without heart failure among patients with acute MI (25). Therefore, the parameters that involve these patient groups provide more accurate evidence about surveillance without a doubt. Moreover, LAd/LVEF may indicate HFpEF and contribute to mortality by that way. In addition, HFpEF was shown to be directly related to age owing to cardiac functional and structural changes were accelerated with increasing age (27). In this study, age was an independent factor in the fully adjusted model. This being the case, it can be stated that we have revealed the underlying $\mathrm{HFpEF}$ patients by studying the LAd/LVEF ratio. Therefore, this ratio can be evaluated with further studies as a new marker in patients with suspected HFpEF.

The association between renal function and cardiovascular diseases is well validated. Especially, renal dysfunction is common comorbidity in patients with HF and ACS and is related to short and long-term adverse outcomes $(29,30)$. Along similar to previous studies, we showed that the serum creatinine predicted the MACE in patients with ACS, independently. Renal function assessment may be added to the prediction models of MACE in future studies. There are various limitations to admit. It is a single-center study conducted with heterogeneous patient groups including relatively inadequate number of patients. Measurements were made by M-mode echocardiography which was found to be inferior compared to left atrial volumetric assessment. Therefore, due to LAd does not consistently indicate LA volume, the power of the present study may be lower than would be conducted by LA volume measurements. One the other hand, simple M-mode LA size measurements are suggested in daily clinical practice still. Lastly, LAd/LVEF ratio had relatively weak value predicting long term MACE.

\section{Conclusion}

The significant relationship was found between the LAd/LVEF and MACE in the present study. This new, simple, and easy applicable indices at admission and during the follow-up in predicting adverse events would facilitate clinical guidance. In addition, the combination of systolic and diastolic parameters may be more logical predicting MACE due to each is associated with. Besides, this ratio might be giving a clue about HFpEF in patients with ACS or normal population. However, this association should be elucidated by further studies with a large population.

Ethical Approval: Ethics Committee of Recep Tayyip Erdogan University Ethic Committee numbered by 40465587-050.01.04 on 24.06.2020

\section{Author Contributions:}

Concept: $M C_{\zeta}, A S Y$

Literature Review: GÇ, ASY

Design : ÖFÇ, MÇ

Data acquisition: $A S Y, M C ̧$

Analysis and interpretation: ÖFÇ, $M C ̧$

Writing manuscript: ÖFÇ, ASY

Critical revision of manuscript: ÖFÇ, GÇ, MÇ

Conflict of Interest: The authors have no conflicts of interest to declare.

Financial Disclosure: This research received no grant from any funding agency in the public, commercial or not-for-profit sectors. 


\section{References}

1 Tong DC, Wilson AM, Layland J. Novel risk factors for acute coronary syndromes and emerging therapies. Int J Cardiol. 2016;220:815-24.

2 Blume GG, McLeod CJ, Barnes ME, Seward JB, Pellikka PA, Bastiansen PM, et al. Left atrial function: Physiology, assessment, and clinical implications. Eur J Echocardiogr. 2011;12(6):421-30. 3 Hoit BD. Left atrial size and function: Role in prognosis. J Am Coll Cardiol. 2014;63(6):493-505.

4 Hamatani Y, Ogawa H, Takabayashi K, Yamashita Y, Takagi D, Esato $\mathrm{M}$, et al. Left atrial enlargement is an independent predictor of stroke and systemic embolism in patients with non-valvular atrial fibrillation. Sci Rep. 2016;6:31042.

5 Froehlich L, Meyre P, Aeschbacher S, Blum S, Djokic D, Kuehne $M$, et al. Left atrial dimension and cardiovascular outcomes in patients with and without atrial fibrillation: A systematic review and meta-analysis. Heart. 2019;105(24):1884-91.

6 Siontis GCM, Branca M, Serruys P, Silber S, Räber L, Pilgrim T, et al. Impact of left ventricular function on clinical outcomes among patients with coronary artery disease. Eur J Prev Cardiol. 2019;26(12):1273-84.

7 Collet J-P, Thiele H, Barbato E, Barthélémy O, Bauersachs J, Bhatt DL, et al. 2020 ESC Guidelines for the management of acute coronary syndromes in patients presenting without persistent ST-segment elevation. Eur Heart J. 2021;42(14):12891306.

8 Ibanez B, James S, Agewall S, Antunes MJ, Bucciarelli-Ducci C, Bueno $\mathrm{H}$, et al. 2017 ESC Guidelines for the management of acute myocardial infarction in patients presenting with ST-segment elevation. Eur Heart J. 2018;39(2):119-77.

9 Aydogdu S, Güler K, Bayram F, Altun B, Derici Ü, Abaci A, et al. 2019 Turkish hypertension consensus report. Turk Kardiyol Dern Ars. 2019;47(6):535-46.

10 Sonmez A, Haymana C, Bayram F, Salman S, Dizdar OS, Gurkan $E$, et al. Turkish nationwide survEy of glycemic and other Metabolic parameters of patients with Diabetes mellitus (TEMD study). Diabetes Res Clin Pract. 2018;146:138-47.

11 Ahluwalia N, Dwyer J, Terry A, Moshfegh A, Johnson C. Update on NHANES dietary data: Focus on collection, release, analytical considerations, and uses to inform public policy. Adv Nutr. 2016;7(1):121-34.

12 Tascanov MB, Tanriverdi Z, Gungoren F, Besli F, Erkus ME, Gonel A, et al. Association between the No-Reflow Phenomenon and Soluble CD40 Ligand Level in Patients with Acute ST-Segment Elevation Myocardial Infarction. Med 2019;55(7):376.

13 Tascanov MB, Tanriverdi Z, Gungoren F, Besli F, Erkus ME, Altıparmak iH, et al. Relationships between paroxysmal atrial fibrillation, total oxidant status, and DNA damage. Rev Port Cardiol. 2021;40(1):5-10.

14 Stefano GT, Zhao H, Schluchter M, Hoit BD. Assessment of echocardiographic left atrial size: Accuracy of M-mode and twodimensional methods and prediction of diastolic dysfunction. Echocardiography. 2012;29(4):379-84.

15 Kobayashi A, Misumida N, Fox JT, Kanei Y. Prognostic Value of Left Ventricular End-Diastolic Pressure in Patients With NonST-Segment Elevation Myocardial Infarction. Cardiol Res. 2015;6(4-5):301-5.

16 Beinart R, Boyko V, Schwammenthal E, Kuperstein R, Sagie $A$, Hod $H$, et al. Long-term prognostic significance of left atrial volume in acute myocardial infarction. J Am Coll Cardiol. 2004;44(2):327-34.

17 Tsang TSM, Abhayaratna WP, Barnes ME, Miyasaka Y, Gersh
BJ, Bailey KR, et al. Prediction of cardiovascular outcomes with left atrial size: Is volume superior to area or diameter? J Am Coll Cardiol. 2006;47(5):1018-23.

18 Gardin JM, McClelland R, Kitzman D, Lima JAC, Bommer W, Klopfenstein HS, et al. M-Mode echocardiographic predictors of six- to seven-year incidence of coronary heart disease, stroke, congestive heart failure, and mortality in an elderly cohort (The Cardiovascular Health Study). Am J Cardiol. 2001;87(9):1051-7. 19 Benjamin EJ, D'Agostino RB, Belanger AJ, Wolf PA, Levy D. Left atrial size and the risk of stroke and death: The Framingham Heart Study. Circulation. 1995;92(4):835-41.

20 Gupta DK, Shah AM, Giugliano RP, Ruff CT, Antman EM, Grip $\mathrm{LT}$, et al. Left atrial structure and function in atrial fibrillation: ENGAGE AF-TIMI 48. Eur Heart J. 2014;35(22):1457-65.

21 Mo BF, Lu QF, Lu SB, Xie YQ, Feng XF, Li YG. Value of combining left atrial diameter and amino-terminal pro-brain natriuretic peptide to the CHA2DS2-VASc score for predicting stroke and death in patients with sick sinus syndrome after pacemaker implantation. Chin Med J (Engl). 2017;130(16):1902-8.

22 Gerdts E, Wachtell K, Omvik P, Otterstad JE, Oikarinen L, Boman $\mathrm{K}$, et al. Left atrial size and risk of major cardiovascular events during antihypertensive treatment: Losartan intervention for endpoint reduction in hypertension trial. Hypertension. 2007;49(2):311-6.

23 Perelshtein Brezinov O, Klempfner R, Zekry S Ben, Goldenberg I, Kuperstein R. Prognostic value of ejection fraction in patients admitted with acute coronary syndrome: A real world study. Medicine (Baltimore). 2017;96(9):e6226.

24 Bosch $X$, Théroux $P$. Left ventricular ejection fraction to predict early mortality in patients with non-ST-segment elevation acute coronary syndromes. Am Heart J. 2005;150(2):215-20.

25 Pfeffer MA, Shah AM, Borlaug BA. Heart Failure with Preserved Ejection Fraction in Perspective. Circ Res. 2019;124(11):1598-617.

26 Longobardo L, Zito C, Carerj S, Khandheria BK. Left atriumin heart failure with preserved ejection fraction: The importance of function before anatomy. Eur Heart J Cardiovasc Imaging. 2017;18(7):730-1.

27 Redfield MM. Heart Failure with Preserved Ejection Fraction. N Engl J Med. 2016;375(19):1868-77.

28 Chan D, Doughty RN, Lund M, Lee M, Kerr AJ. Target Doses of Secondary Prevention Medications Are Not Being Achieved in Patients With Reduced Left Ventricular Ejection Fraction After Acute Coronary Syndrome (ANZACS-QI 34). Hear Lung Circ. 2020;29(9):1386-96.

29 Anavekar NS, McMurray JJV, Velazquez EJ, Solomon SD, Kober $\mathrm{L}$, Rouleau JL, et al. Relation between renal dysfunction and cardiovascular outcomes after myocardial infarction. N Engl J Med. 2004;351(13):1285-95.

30 Al Suwaidi J, Reddan DN, Williams K, Pieper KS, Harrington RA, Califf RM, et al. Prognostic implications of abnormalities in renal function in patients with acute coronary syndromes. Circulation. 2002;106(8):974-80. 